\title{
Ethical Care in Education: A Secular Humanist vs. an Islamic perspective
}

\author{
by
}

Dr. Mohammed Sabrin

Taibah University

Al Madinah Al Munawwarah, Saudi Arabia 


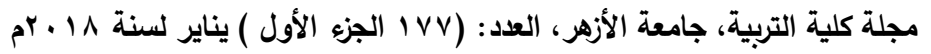

Ethical Care in Education: A Secular Humanist vs. an Islamic perspective

\begin{abstract}
:
In a time of increasing anxiety between 'The Muslim World' and 'The West', it is important to investigate the philosophical assumptions that seem to undergird the two parties' Weltanschauung-particularly as we are slowly realizing that they are not neccesarily exclusive entities. However, given the gravity of what is at stake, it seems imperative to undergo such an exploration through a concrete case-based philosophical study in how these worldviews approach education instead of a merely theoretical discussion. This article is a comparative analysis between Nel Noddings' concept of Ethical Care-and it's application by scholars such as Thomas Lickona and Becky Bailey - and the author's selection of what seem to be the most relevant aspects of Islamic Pedagogy. Particular emphasis is placed upon comparing the Secular Humanist philosophical assumptions underlying Ethical Care in its Western form and the Islamic philosophical assumptions underlying Islamic Pedagogy with the objective of finding common ground between two worldviews presumably in tension-while acknowledging differences where each can benefit from the other.
\end{abstract}

Keywords: Secular Humanism, Modernism, Islam, Pedagogy, education, comparative education,

\title{
Introduction:
}

Education could be said to involve two processes, official curriculum content and moral education; in other words while a particular subject matter is being taught, teachers also educate and socialise students into the accepted value system of their society either directly or indirectly. While much of the literature in the field of education has focused on the cognitive aspects of education, more recent research has highlighted the importance of discussing what kind of moral education goes on in the classroom (Lickona, 1991; Moore, 2007). In America, values are often derived from the liberal arts public education system, citizens' various personal religious beliefs, or some combination of both (Moore, 1-10, 2007). Herein lies a comparison between the liberal arts value system, which $I$ have referred to as the broader belief system of 'Secular Humanism' dominant in Western countries since 'The Enlightenment', and one particular theological belief system-Islam. I will analyse the theoretical framework of 'ethical caring' laid out by Nel Noddings of the ideal student/teacher 


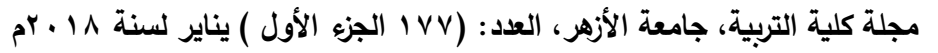

relationship and the pragmatic contributions of Thomas Lickona on how to utilise such a relationship to teach values in the classroom. I will compare these arguments to a similar analogue of ideal student/teacher relationships found in Islam, which will highlight similar concepts in theory, but some different suggestions in regard to application. This comparative study will illustrate how peoples with differing belief systems as frameworks for viewing the world - the human-centered Secular Humanist perspective as opposed to the God-centered Islamic one-can come to similar conclusions on issues while respecting each others' differences within their respective contexts. Such research is important at a time that a return to traditional organized conceptions of 'religion' is apparently becoming a global phenomenon. However, it is important to first clarify the important role that 'the affective' has been found to play irrespective of whether one is concerned with teaching morals, more 'traditional' notions of the cognitive, or both. The work of Lev Vygotsky, which has drawn significant attention post WWII, will help outline some of the theoretical assumptions that undergird a belief in an 'ethic of care.'

\section{The Philosophical Assumptions Underlying a Belief in an Ethic of Care}

Lev Vygotsky was one of the earliest scholars to comment on the importance of reconnecting the link between cognitive and affective factors when researching the human psyche (Goldstein, 648, 1999). Vygotsky defined a 'zone of proximal development' as 'the distance between the actual developmental level as determined by independent problem solving and the level of potential development as determined through problem solving under adult guidance or in collaboration with more capable peers' (as cited in Goldstein, 649, 1999 emphasis added). Therefore, using a customised student-centered pedagogy, an educator could scaffold a student along to higher, more intricate concepts (building on their previous knowledge) depending on the supportive guidance received either from the teacher or other peers who had comprehended the concept (Goldstein, 649-654, 1999). Vygotsky realised that learning is not simply an individual activity (otherwise not much disciplinary analysis would be needed outside of a psychological lens), and that more insightful analysis of educational development needs to be discussed in relation to the social interactions that take place between the actors involved. Accordingly, by developing deeper relationships with their students, educators can consciously care for students in a way that provides a suitable environment for growth. Such deliberate attention to students' needs on the part of the educator will also provide a role model for other students to help each other grow in cooperative learning settings. 


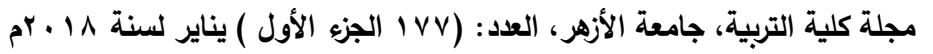

Ethical Care: The Theory:

Many scholars have elaborated on the nature of this affective and caring relationship between teacher and student (Bailey, 2000; Noddings, 1984; Rogoff, 1990). At the time that Nel Noddings wrote Caring: A feminine approach to ethics and moral education (1984), she was responding to a growing sentiment (as evident through the increasing moral education literature at the time) that more attention should be paid to treating students like humans who need time, attention, and guidance to intellectually and emotionally develop (Lickona, 1991). Noddings took this concept a step further by clarifying that an educator has a moral obligation and responsibility to actively care for their students and embody the values they want to instil in them by virtue of the educator's position as a role model (Noddings, 1984). She goes as far as to say that the one-caring (the educator) must 'receive' the cared for (the student) into themself by being 'engrossed' with their goals and needs; this motivational displacement involves temporarily preferring the student to one's self (Goldstein, 656, 1999). On the part of the cared for they are expected to somehow acknowledge or reciprocate this care in every caring encounter (Goldstein, 657, 1999), but are not ordered to (Noddings, 72, 1984). In fact, this reciprocity could involve the teacher being directly acknowledged or simply witnessing the cared for's happy growth (Noddings, 74, 1984).

Consequently, Noddings (1984) has differentiated between naturally caring and ethically caring for one's students; the former is not a reliable form of care because the educator might simply not naturally care for or be drawn to a particular student, while the latter involves an active, professional choice to care acknowledging an ethical obligation. Ethical caring is an action, not a quality. A student/teacher relationship based on ethical caring is more important because naturally caring for all of one's students may or may not occur. Also, people are naturally more drawn to those they are similar to in some way, in which case natural caring would not suffice for equitable guidance of students. Educators should choose to care in strategic ways, irrespective of whether natural caring develops over time or not. Ethical caring demonstrates a sincere dedication on the part of educators to help students grow, whether they are having a bad day or not, whether they 'like' the students or not; this choice requires a genuine belief in children's ability to succeed, which empowers the teacher and student throughout the learning process. Such a practical tailored approach to each child helps students develop intellectually and morally. While this caring approach seems ideal in explaining what should be done, one question is left unanswered, how do we motivate practitioners to care? Why should they maintain a 'concern for the ethical self' 


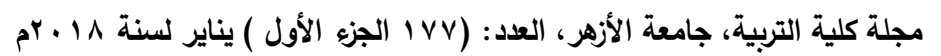

(Noddings, 75, 1984) in the unpredictable daily hustle and bustle of over-energised children, increasing discipline problems, and even occasionally violent behaviour? This question will be addressed in the discussion of Islamic pedagogy, but first let's look at some practical examples of Noddings' approach in the field.

\section{Ethical Care: In Practice- The Contributions of Thomas Lickona and Becky Bailey}

Concerned about the moral state of youth in his time, Thomas Lickona undertakes the task of outlining a detailed stratagem for the practical application of a caring pedagogy. Lickona applies the concept of Vygotsky's 'ZPD' to not only demonstrate the importance of teachers taking active roles in helping their children cognitively and morally develop, but that the teachers themselves must embody the potential results of that development. He particularly goes a little further than Noddings by highlighting that one's private life affects their public behaviour (Lickona, 49, 79 1991). One has to become a role model of the behaviour one wants to see in students; the caring relationship that will be developed is what will allow students to reach their potential development intellectually and emotionally. An artificial façade played out every time a teacher comes to class is easily seen through; Lickona states, 'we are coming to see that our societal moral problems reflect, in no small measure, our personal vices' (Lickona, 49, 1991). On the issue of role models one could also add to this that on a macro level, the leaders of the nation should be the first exemplars in demonstrating these morals on the world stage for them to really have any effect and trickle their way down to the masses. However, the causal direction of social change is not predetermined as far as we know, and teachers are in the best position to effect long-term societal change from the roots up-through the children that will inherit their legacy.

Undoubtedly, one has to truly change oneself before one can hope to be a role model for others. Doing so will pragmatically show children how to identify when moral action/judgment is needed, how to reflect on it, and then act. By using daily occurrences, positive or negative, in the classroom as teaching moments instead of mere disruptions, Lickona shows how educators can act out the moral reflection process right in front of their students. Teachers can literally 'think out loud' when a teaching moment occurs, about their primary reaction to it, the weighing of opportunities for possible further action, and then following through assertively to respond to the situation. This process could involve for example teachers modelling composure as they pause to deliberate a situation requiring a moral decision, making value judgments in front of students as to the particular 


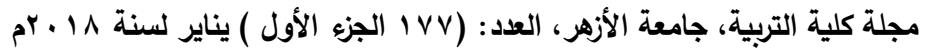

pros and cons of a particular course of action, and then acting (Lickona, 54-57, 1991). This process of using classroom incidents as teaching moments is well known among educators as casebased learning. Modelling moral reflection in front of one's students will pragmatically show them how to consciously represent the values they profess.

Lickona also gives examples of how the lack of role models to model moral behaviour cannot even be substituted for by any of the material recompense (i.e.: candy, etc.) that is often offered to children for 'good' behaviour. Role models pass on their morals to others they interact with since moral behaviour is a social act that is enacted publicly and affects everyone involved. Ergo, the better students treat others socially, the better they will feel about themselves internally. Accordingly, lack of such role models leaves many students in despair, selfishness, and loneliness. Children without role models are often left undisciplined and only interested in material consumption (Lickona, 50, 1991). Many are slowly realising that material pleasures will never substitute for human interaction.

Educator Becky Bailey offers some complimentary hints as to the background disposition needed for teaching morals, the importance of maintaining composure at all times so that one maintains control and assertiveness no matter what the situation (Bailey, 26-30, 2000). To actually maintain composure, given the hectic bustle of life in the classroom, one should differ between 'management demands' and 'moral demands' (Kohlberg \& Selman, 39, 1972); by stressing serious moral infractions much more than the usual spills and misunderstandings, educators can prioritise their demand of children's short attention spans/ mental capabilities. Only with a composed demeanour can one act purposely, and not off mere emotion, a temperament essential for moral reflection. Also, the importance of acknowledging accomplishments through praise and other methods by the educator is crucial for encouraging students along throughout their moral growth (Bailey, 82, 85, 92, 2000).

Lickona describes the aforementioned procedure for exemplifying moral reflection by saying that 'good character consists of knowing the good, desiring the good, and doing the good-habits of the mind, habits of the heart, and habits of action' (Lickona, 51, 1991). A striking parallel will be seen to this method in Islam of how once someone has knowledge of a virtue, they purify their intention to do it, and then carry out the action. Some teachers even use 'ethics journals' that helped students to critically reflect on their daily actions in the process of developing effective moral reflection skills (Lickona, 56, 1991). 


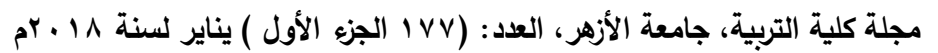

Cooperative learning activities are also opportunities to develop bonds between students so that they can assist each other in modelling moral behaviour (Lickona, 74, 1991), while still allowing opportunities for teachers to interject their own moral feedback and guidance (Lickona, 85, 1991). The feedback on behaviour is recommended to be given in private, guiding students to understand why what they did was inappropriate, and is followed up on to monitor progress (Lickona, 86, 1991). Through cooperative learning, students experience 'trial and error' opportunities to practise moral reflection and action, and are then scaffolded to the desired objective through caring educators' guidance. Students' participation in their own moral growth empowers them to begin to act independently, raises their selfesteem, and has longer effects on their long-term behaviour. Accordingly, Lickona has outlined a framework for developing a caring student/teacher relationship and the process for utilizing this relationship to teach moral education, either directly between student and teacher or through 'mini-role models' created in cooperative learning structures. Given that Lickona has shown us how moral behaviour should be taught, He also gives suggestions for what values should be modelled.

Lickona advises educators to start with the core values of respect and responsibility and then build upon these concepts a customised set of morals (such as honesty, tolerance, fairness, prudence, self-discipline, compassion, cooperation, and courage) according to contextual needs (Lickona, 43-44, 1991). Lickona acknowledges that 'getting agreement about shared values does not, of course, guarantee that people will agree about how to apply those values in every situation' (Lickona, 47, 1991). This potential ambiguity illustrates once again the importance of using the casebased approach outlined above. By using the curriculum, 'disturbances', and other opportunities in the classroom to model good morals, ethical behaviour is no longer as challenging (Lickona, 62, 69, 72, 1991). Teachers who develop caring relationships with students can 'help students to experience the world from the perspective of others' (Lickona, 55, 1991), an ability essential for teaching respect.

\section{An Islamic Perspective Towards Ethical Care:}

In Islam-which means 'submission' in Arabic (i.e.: to God's law as defined by the Qur'an (believed to be the literal word of God) and the Sunnah (the Prophet Muhammad's, peace

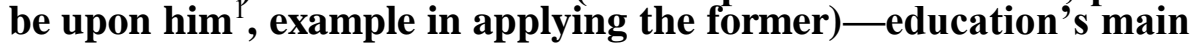
concern is actually moral education. The entire Qur'an primarily

1 This is a gesture of respect often said by Muslims when mentioning the Prophet's name. 


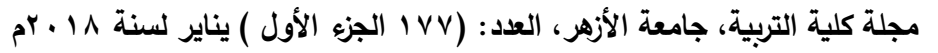

refers to the ethics one should uphold when dealing with their lord, family, and surrounding society. Like many belief systems, Islam views moral behaviour as a constant need for any society, because positivistic and other human-based sciences will vary with the time and location of the people/environment, but proper social interaction is irreplaceable. Historically, there was never an artificial barrier constructed between empirical sciences and revelation because Islam legislated that two Truths cannot contradict each other. Tawheed (the belief that none is worthy of worship except God) implies a certain unity and intrinsic harmony in the universe due to the oneness of the creator (Progler, 2001). Indeed, the principles and character of a society are its foundation. It is through an ethical foundation that humans would benefit others through the other forms of knowledge that they would be later scaffolded to, like the empirical sciences. Humans' morals would ensure they used whatever power, resources, or abilities they acquired throughout their lives to contribute back to society.

The first words revealed to Prophet Muhammad (peace be upon him) of the Qur'an were, what means, 'Read/Recite! In the name of your Master, who has created all that exists...' (Qur'an, 96:1). Acquisition of Knowledge in Islam-the two types being that gained through revelation and that gained through the senses-is justified and directed by the provision that all knowledge gained be used in worship of the Creator (worship being widely defined as anything that pleases God as outlined in the Qur'an and Sunnah, from fasting to sexual relations with one's spouse). The most important type of knowledge in Islam is theological, understanding the will and nature of God through the Qur'an and Sunnah (Uthaymeen, 2004), because only after a theological foundation would an individual know how to live their life Islamically no matter what field or practise they went into professionally. Proper character ensures knowledge is used for the benefit of society. Hence, character education in Islam is analogous to the role played by civic education in Western secular societies. Prophet Muhammad said ' $I$ have only been sent to correct people's manners' (Bukhari, 37 in USC). In fact, it is through these proper 'manners' (taken broadly in Arabic to mean proper interaction with one's Master, family, society, etc.), that God would teach humans that which would benefit them (Qur'an, 2:282).

\section{Role Modelling in Islam:}

The pedagogy used throughout much of Muslim civilization was that of Prophet Muhammad, believed to have been one of a loving teacher leading by example and teaching a customized curriculum - in a dialectical manner. This curriculum 


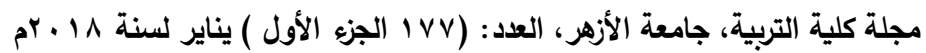

emphasized a foundation of moral character and application of knowledge in one's behaviour for the benefit of society (Berkey, 1$38,1992)$. The personal feel of this student/teacher relationship was seen in the fact that quality education in Muslim societies hinged less on books, than on that one actually learned from. Students of Islamic theological knowledge used to spend their whole lives traveling to sit with the greatest of scholars and learn from them how to live by what they learned and practically apply it to become closer to God (Berkey, 22-38, 1992). Such a pedagogy was because possessing true Islamic theological knowledge meant living by it; after all, what good is knowledge that doesn't benefit? Hence, when students received an ijaza ('authorization to pass on their knowledge') from scholars, it was for how much they knew and applied. This was only earned after years of this apprenticeship type relationship where scholars had watched them grow and assessed their behaviour in various communal settings (i.e.: with the general public and fellow students) (Niell, 484-485, 2006). As Islamic theology scholars modelled the moral behaviour they wanted to develop in their students, education became an active reflective process. The scholars are the 'inheritors of the prophets' notes a hadeeth, meaning they acquired proper moral conduct through their knowledge of the scriptures, but more importantly through daily practise with their mentors (Uthaymeen, 3, 2004). In the Qur'an, this is actually the reason that messengers were sent, to bring their respective books of revelation, and set the example of how to apply them, thereby purifying them from lowly behaviour (in Arabic tazkiyah) (Qur'an, 2:151). Those who learn Islamic theological knowledge after them continue this legacy by acquiring proper morals from righteous people who model them. Actions speak louder than books. This is the importance of modelling the values one aims to teach in Islamic pedagogy.

The aforementioned modelling of moral behaviour in Islamic pedagogy is what Lickona focused on as the first step to teachers teaching morals, embodying them first, and ridding themselves of their 'personal vices.' Seeing moral behaviour, students can comprehend what proper behaviour looks like, intend to live by it, and then actually start trying their best to do so. The apprenticeship relationship that illustrates to students how to go through this process is analogous to the case based learning methods that might be utilized by Lickona-inspired educators in the classroom as mentioned above-using daily incidents of life as teaching/learning opportunities. 


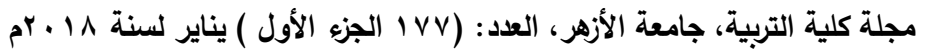

Ethical Caring in Islam:

To better understand the caring relationship in Islamic pedagogy, we could also look at the Arabic linguistic meanings of 'education' in Islam. 'Tarbiyya', the closest parallel to 'education' in Arabic, means to educate, discipline, cultivate, and raise caringly to maturity. Tarbiyya also comes from the same root as 'rub' (lord or master) showing the authority that exists with the teacher; in respect to God Himself this refers to the God who cultivated and raised up humans in a state of dignity 'teaching them that which they did not know' (Qur'an, 96:6) and in relation to humans it shows the tremendous respect and authority an educator has in Islam (Neil, 483-485, 2006) due to his/her immense responsibility to cultivate society. Most convincing is that the root of all these terms is the term 'rubaa', which literally has the agricultural connotation of a farmer caring for a tender plant. Herein lies the motivation for an educator to care about their students in Islam; it is their spiritual Islamic obligation. This motivation for caring is slightly different from Noddings' concept of reciprocity (74, 1984), which expects some form of human motivation or reward for caring. Hence, theological motivations on the part of teachers who believe in the metaphysical can serve as a complimentary addition to Noddings' conception of Ethical Caring.

\section{Motivation for Caring in Islam:}

In Islam, all good deeds must be done for the pleasure of God. Prophet Muhammad is believed to have said, 'the reward of deeds depends upon the intentions' (USC, 1). Accordingly, the attitude towards Noddings' 'reciprocity' $(74,1984)$ in Islamic pedagogy would depend on the form it takes. If it was initiated on the part of the student in the sense of applying the knowledge (and the educator happens to witness this 'happy growth'), then this might be praiseworthy as this could be indicative of the student's sincerity (one of the two conditions for good deeds to be accepted in Islam) in learning to become more God-conscious (assuming there's no worldly pretentiousness about desiring to be looked up to by others or fame involved). In this sense, the educator sees the fruits of his/her labour, which is a possible sign of God's acceptance of his/her deeds in Islam. On the other hand, if the reciprocity takes the form of gifts or praise for the teacher, then this could cause possible harm to the teacher by inflating his/her's ego if he/she attributes the outcome to themselves (and not to the mercy of God for allowing them to achieve the good they did), possibly nullifying the reward for their deeds. Furthermore, if the educator expects such reciprocity from the student, then this makes his sincerity questionable from the beginning, because a Muslim expects his reward solely from God. 


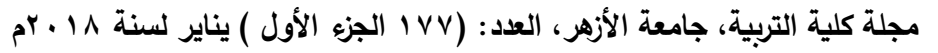

In Islam, God has created humankind to worship Him and blessed them with innumerable blessings, foremost of which is creating them; therefore, they are obligated to reciprocate this bounty with obedience, and though $\mathrm{He}$ is not required to, He has chosen to reciprocate to them paradise for their obedience. This issue of maintaining sincerity is so crucial in Islam that one is expected to choose their company of only those who they believe to be sincere (Qur'an, 18:28); this is why the teacher's function as a role model is so important, because the students will emulate him/her and serve as peer role models in cooperative group tasks with other students. Hence, creating good company and a moral environment in the classroom minimizes the need for repetition of the teacher's efforts. This is an assertion Vygotsky would wholeheartedly agree with since he acknowledges the contagious nature of behaviour between people (Goldstein, 648-654, 1999).

\section{Possible Controversy Over Using 'Religion' as a framework to Model Values:}

Given the secular nature of Modernism, a liberal arts academic might argue that using a spiritual motivation for caring is not universal, since some do not believe in a higher being for example. Such motivation is dependent on 'respect for God and God's authority; it is not an autonomous human value' (Kohlberg \& Selman, 1972). However, this statement is also problematic because it presumes that there is some consensus on what is a 'human value', and that a secular lifestyle is even acceptable in the first place. Although many of us believe our own beliefs are what should be the logical universal values, humans differ vastly over the definitions of things like justice for example or whether one should prioritize equity or equality for example. A classic example is the belief in 'eye for an eye' in most traditional organized religions whereas most Secular Humanist countries rarely apply such a concept; hence, we might have universal words, but we also have wide disparities in definitions for them.

Another example of the lack of universality behind the definitions of 'universal human values' is the limits drawn on individual freedom and liberty to prevent societal harm (and even what constitutes this latter term). These limits are widely differed over in America alone, let alone the rest of the universe, and the examples are endless. Accordingly, it would be very dehumanizing to entire sections of the planet for small isolated groups of academics in a handful of countries to decide what human activity should look like all over the world. Simply labelling one's own values 'universal' does not make them as such. A more realistic solution would be to promote specific values which are to be lived by (even if not intellectually agreed upon) on a domestic level, while promoting tolerance of others on an international one- 


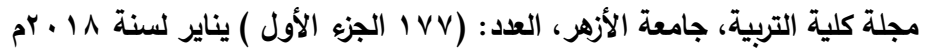

domestic nationalism and international pluralism. This leaves more options open for humans to live their definition of a meaningful life without interfering with others'. Having addressed the possible concern over the universality of values, I would like to return to how such caring encounters, where moral values are taught and modelled, take place between student and teacher in Islam.

\section{Scaffolding Moral development in Islam:}

According to the Qur'an, one of the main reasons that the Qur'an was revealed piecemeal over 23 years is specifically because changing human behaviour is a gradual process; hence, verses revealed in Mecca when Muslims were still oppressed and persecuted focused on attaching people's hearts to the fundamental beliefs of Islam-that since there is only one God, only He is worthy of being worshipped, and belief in the Day of Judgment, when humans would be held accountable for their deeds and accordingly granted paradise or hellfire (Uthaymeen 9, 2004). As Muslims developed deeper knowledge of their faith and practised it, they increased in numbers and strength and immigrated to Medina, establishing a society there. During this process, verses were revealed which increased acts of worship to their final amounts and outlined the laws for the finer details of day-to-day societal interaction (like political, social, and economic legislation).

The Arabs in pre-Islamic Arabia were living in relative savagery; they would bury their female children and sell women as property, have random sexual relations, drink extremely heavily, and other crude behaviour (Uthaymeen 8-15, 2004). People do not generally dramatically change overnight. Therefore, Islamic legislation took them step-by-step scaffolding them through formal refinement; Aisha, the wife of Prophet Muhammad, best described the wisdom behind the order of revelation by noting

If the first verses revealed commanded to not drink alcohol or commit adultery, the Arabs would have said 'By Allah, we'll never stop'; however, the first verses that were revealed discussed only worshipping the Creator, and paradise and hellfire as a consequence for actions on a Day of Judgement, until the hearts become firmly attached to and loving their Master. Then came down the verses with the commandments about what was permissible and not permissible (Muslim 344 in USC).

Similarly, children are like blank slates; we cannot assume that they should know better, because for many things they do not and have not been taught, so one should take time and caringly show them appropriate behaviour. When done at a young age, 


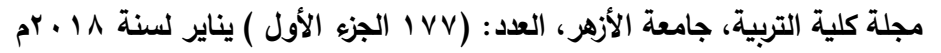

such caring instruction is like etching these values into the child's memory. A young boy was once eating with Prophet Muhammad, but he was not doing so according to Islamic etiquette; he was not eating from his side of the plate, but rather eating from all over it. The Prophet said to him 'Oh, young boy (a term of endearment in the Arabic way it was expressed)! Say Bismillah (with the blessing of God), eat with your right hand, and eat from what is directly in front of you.' The boy commented later, 'this remained my way of eating from that time on' (Bukhari, 5376 in USC). Prophet Muhammad did not scold him for what he was doing wrong, but rather immediately proceeded to simply instruct him what the right way was, an approach to correcting mistakes that has also been promoted by Bailey.

\section{Drawing Connections between Secular Humanist and Islamic Pedagogy:}

Bailey also suggests not focusing on what children are doing wrong as to damage their self-esteem, but to rather simply tell them how they can do it correctly. This is a much more positive approach to correcting mistakes. Don't just say 'don't do this or that', but rather educate children on the important part, what they should be doing (Bailey, 55-73, 2000). The Secular Humanist and Islamic perspectives have promoted a forgiving optimistic approach to teaching children. Prophet Muhammad is quoted as saying 'he is not one of us [a Muslim] who does not show mercy to children (Dawud 764 in USC).

Similar to Lickona $(55-67,1991)$, there are numerous examples where Prophet Muhammad stressed explaining the reasons to people why what they are doing is wrong, and not hastening to condemn them (Bukhari, 717, 4992 \& al-Nisaa'i, 4999 in USC), many times offering them more appropriate alternatives (al-Nisaa'i, 1119 in USC). Even when a bedouin man had once urinated in the mosque's prayer area, because he had not realized that it was different from any other place, Prophet Muhammad commanded his companions to not interrupt him, nor yell at him. Rather, after the man finished Prophet Muhammad simply explained to him that it was inappropriate to do so in a prayer area of a mosque and had the area cleaned. After this the Bedouin was so impressed by the Prophet 's caring attitude to a complete stranger that he supplicated 'oh God, forgive me and Muhammad and no one else [an implicit jab at the companions of Prophet Muhammad]' (Muslim, 285 in USC). Admonishment by itself is not a true learning experience; how proper moral conduct is taught is the essence of the message. 
Also, once when some young girls were eulogizing the deaths of their fathers in a recent battle, they started praising Prophet Muhammad in a way that was not befitting of him by saying that he knew the future; however, he did not prohibit them from mourning their dead fathers, but told them to simply take out the part which exaggerated his capabilities. In this way, he removed the mistake they were making, but allowed them to continue with their eulogy. Accordingly, teachers should not focus on the faults of students, but be balanced in celebrating their good behaviour. Educate students on how to do things correctly instead of complaining about what they are doing incorrectly as Bailey has suggested (Bailey, 55-73, 2000). Compassion is key.

\section{Further Moral Reflection:}

One of the primary goals of case based learning, as discussed by Lickona above (Lickona, 47, 1991), is for students to realize when a situation requires moral action, reflect on it, and then act upon it. By revealing the doctrines of Islam piece by piece, there was live explanation and application of the verses by Prophet Muhammad in front of his companions so that they could see what it actually looked like in practise to uphold one's covenants, maintain ties of kinship, help the poor, be humble, etc.. Morals as general themes always sound wonderful, but the key is developing the wisdom to know how to prioritize values and contextualize them to one's situation. Most would agree that lying is wrong for example, but would also agree that it could be commendable if it was going to save an innocent person's life.

In Islam, developing such a discerning nature is called having fiqh ('deep understanding') of the faith, not just knowing the 'dos and don'ts', but truly comprehending the principles and value system of Islam to the extent that one is able to do the best most beloved act to God contextual to the time and place. Prophet Muhammad described this when he stated that 'whomever Allah desires good for, He gives him/her deep understanding of Islam and the insight of how to apply it properly' (Bukhari, 302 in USC). This is an importance of case based learning that Secular Humanist and Islamic approaches to moral education would agree on-developing critically conscience morality. I will illustrate some more examples of such cases.

In regards to values, Islam legislates very similar moral values to the Secular Humanist framework like: honesty, cooperation, responsibility, forgiveness, courage, self-sacrifice, and discipline (Qur'an, 2:177). However, a crucial disposition that Bailey highlighted (26-30, 2000) was the importance of maintaining composure throughout the daily opportunities for modelling these morals; this is also the backbone of Islamic pedagogy. Numerous ahadith (pl. of hadith) of Prophet Muhammad mention the importance of maintaining one's wakaar 


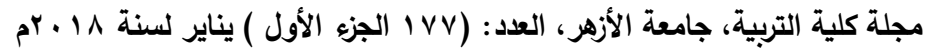

(composure) (not to mention being from the most often repeated characteristics of an ideal believer at the end of chapters Lukman and al-Furqan in the Qur'an). One of the most famous examples of wakaar is when a man had come to Prophet Muhammad and kept asking him to give him an invaluable piece of advice (expecting some long complicated response) and Prophet Muhammad kept simply telling him to not get angry in two words (Muslim, 1077 in USC). The man had travelled a far distance to obtain some profound wisdom from this Prophet he had heard about, and the Prophet told him to not get angry. Nonetheless, the wisdom of not getting angry as one's disposition is profound; how many learning opportunities are lost when educators cannot calmly morally reflect on a situation before acting?

\section{Prioritizing Values:}

In order to practically maintain one's composure, one needs to always maintain an upbeat optimistic disposition and not be flustered easily, thereby being able to be lenient with minor occurrences of misconduct, but able to clamp down with major infractions as was suggested by Bailey. Modelling prioritization of values was also seen in Prophet Muhammad's interaction with children like Anas. Anas stated 'I served the Prophet Mohammad (pbuh) (and his family) for ten years. (During these 10 years) he never got angry with me nor asked why I did this or didn't do that' (Bukhari 418 in USC). This was the tolerance and compassion Prophet Muhammad displayed towards children since they were still developing and learning. However, this was all regarding issues that were offenses to one's person, but when it came to important matters, like religious infractions he would say things like 'teach your kids to perform their prayers by the age of seven, and spank them [Muslims are not allowed to hit other humans in the face or hard enough to leave a mark unless in combat or if a government official is administering punishment for a crime, etc.] if they are not performing them by the age of ten' (Bukhari 677 in USC). Refusing to perform the five daily prayers is complete disbelief in Islam. Hence, the teacher is expected to be 'naturally' caring as part of his/her Islamic personality by default, but has the ability to be harsh when needed regarding such pivotal issues.

The aforementioned is the parallel in Islam to differentiating between moral and management demands as was expressed by Kohlberg and Selman above (Kohlberg \& Selman, $20,1972)$. One must be very lenient while trying to help their students learn proper moral behaviour-because if they highlight every mistake a child makes throughout the day, they'll never get through a lesson-but they can save their emphasis for the fundamental values they are trying to instil. 
The last example I will discuss is regarding Lickona's use of cooperative work to teach children how to teach and learn from each other (Lickona, 74, 1991). Prophet Muhammad would often put up a question for discussion when intending to teach something. Once Prophet Muhammad was with some companions and asked 'Indeed there is a tree that does not shed its leaves, and resembles a Muslim. So tell me, which is it?' So people started discussing the trees of the countryside. Abdullaah ibn 'Umar said 'I thought to myself that it was the date palm tree, but I was shy and did not speak up' (this is because he was very young and did not want to interrupt the elders). So they asked the messenger, 'tell us what it is Oh messenger of Allah.' He said 'it is the date palm tree.' Ibn 'Umar mentioned to his father how he had known the answer, who replied 'It would have been more beloved to me 'than such and such' [an Arab expression] had you said it was the date palm tree' (Bukhari 167 in USC).

To not go into deep theological commentary on why the Muslim was most like the palm tree, the general reason was because all parts of it are beneficial for some use, compared to most trees that would have been found in Arabia at that time. What concerns us in this comparison is that Prophet Muhammad questioned them to test their general understanding of how a Muslim should be (to get them thinking), gave them time to discuss the issue among themselves, and then come up with answers. He also used an illustrative analogy to convey his point. By having different ages of people within a group, the experience was also one that highlighted the importance of developing assertiveness in children so that they feel comfortable voicing their opinions and feel intellectually safe to make mistakes. Independent critical thinking followed by cooperative discussion seems to be a pivotal process in moral education within the Secular Humanist and Islamic pedagogical paradigms.

\section{Conclusion:}

In conclusion, it has been shown how the concept of ethical caring has potential to be a universal concept or at least a common one between the Secular Humanist and Islamic worldviews. By using socio-culturally relevant frameworks in the field to apply this concept, ethical caring can be promoted to teach teachers how to develop pragmatic caring relationships with their students that help both parties to grow--morally and intellectually. Moral education is a timeless, necessary aspect of any educational system that values social justice and coherence. By living our values, not only do we change society individually, but as teachers we also prove to our students that we believe in what we are teaching. If we don't live by what we say, then who will care? 


\section{Bibliography:}

Bailey, B. A. (2000). Conscious discipline: 7 basic skills for brain smart classroom management. Oviedo, FL: Loving Guidance, Inc.

Berkey, J. P. (1992). The transmission of knowledge in medieval Cairo: A social history of Islamic education. Princeton, N.J.: Princeton University Press.

Dean, A. L. (1994). Instinctual effective forces in the internationalization process: Contributions of Hans Loewalds. Human Development.

Goldstein, L.S. (1999). The relational zone: The role of caring relationships in the co-construction of mind. The American Educational Research Journal, 36 (3), 647-673.

Kohlberg, L., Selman, R. (1972). Preparing school personnel relative to values: A look at moral education in the schools.

Lickona, T. (1991). Educating for character: How our schools can teach respect and responsibility. New York: Bantam Books.

Moore, D. L. (2007). Overcoming religious illiteracy: A cultural studies approach to the study of religion in secondary education (1st ed.). New York: Palgrave Macmillan.

Neill, C. M. (2006). Islam in Egyptian education: Grades K-12. Religious Education, 101(4), 481-503.

Noddings, N. (1984). Caring: A feminine approach to ethics and moral education. Berkeley: University of California Press.

Progler, J. (2001). Encountering Islam. London: Routledge.

Rogoff, B. (1990). Apprenticeship in thinking: Cognitive development in social context. New York: Oxford University Press.

University of Southern California. USC-MSA Compendium of Muslim Texts. Retrieved 12 November 2009 from: <http://www.usc.edu/dept/MSA/fundamentals/hadit hsunnah/muslim/>

Uthaymeen, M. I. S. (2004). Trans: Abu Abdullah Mohammed Akhtar Chaudry. The book of knowledge. Vol. 1. London: Invitation to Islam. 


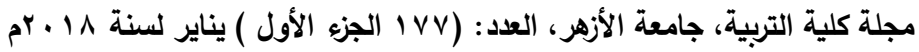

$-7 \leqslant Y-$ 